Ogata, Sadako 2002, Guilty Parties, in: Foreign Policy, 132, 3940.

Roy, Olivier 2004, Globalised Islam, London.

Samuels, Kirsti 2007, Political Violence and the International Community, Leiden/Boston.

Schlichte, Klaus/Veit, Alex 2007, Coupled Arenas. Why statebuilding is so difficult, Working Papers Micropolitics, 3/2007, Berlin.
Tomuschat, Christian 1995, Die internationale Gemeinschaft, in: Archiv des Völkerrechts, 33:1-2, 1-20.

Woever, Ole 1995, Securitization and Desecuritization, in: Lipschutz, Ronnie D. (ed.), On Security, New York, 46-86.

Wedgwood, Ruth 2002, Gallant Delusions, in: Foreign Policy, 132, 44-46.

\title{
Reconstructing Afghanistan:
}

\section{Is the 'West' eclipsing the 'International Community'?}

\section{Eva Gross*}

\begin{abstract}
This article considers the role of the 'international community' in the reconstruction of Afghanistan. Although the UN has a coordinating and legitimizing role, the 'international community' has turned out to be fragmented, and the countries determining policy have predominantly been Western. Current efforts to include regional contributions do not necessarily reflect a more inclusive notion of 'the international community'. Rather than re-investing in the notion of the international community to reach a local, regional as well as international consensus, current thinking on Afghanistan tends to highlight fragmentation of what was initially framed as a task for the international community.
\end{abstract}

Keywords: Afghanistan, international community, NATO, UN, the West, Afghanistan, Internationale Gemeinschaft, NATO, UN, der Westen

\section{Introduction}

A fter the fall of the Taliban, brought about in response to the attacks on 11 September 2001, the task of reconstructing Afghanistan was placed under UN auspices both to lend legitimacy to international efforts and to coordinate economic and political measures on the part of the various international actors involved. Present at the creation of policies towards Afghanistan, however, were two factors that facilitated international fragmentation rather than a coherent and comprehensive approach. The first was the changing nature of international coalitions: the US, rather than calling on NATO for support in its fight against the Taliban through Operation Enduring Freedom (OEF), relied on ad-hoc coalitions of the willing, which put into question the role and purpose of military alliances in the post-11 September era. The second was the emphasis - under the penmanship of Lakhdar Brahimi, the UN's Secretary General Special Representative - on a 'light footprint' approach that emphasized Afghan involvement in setting policy priorities (House of Commons 2003). These two factors led to a severely fragmented international environment

\footnotetext{
* Dr. Eva Gross, Senior Research Fellow, Institute for European Studies, Vrije Universiteit Brussel. The author wishes to thank the two anonymous reviewers for their insightful comments, and the editors for their kind invitation to participate in this special issue. This article is peer-reviewed.
}

in which reconstruction efforts have taken place to date. In light of the deteriorating security situation, the predominant discourse on Afghanistan has focused on military and political commitments among Western actors - the US and its allies, NATO, but increasingly also the EU - rather than a concern with engaging the 'international community'. These actors, which for the purpose of this article will be referred to as 'the West', therefore, have eclipsed 'the international community' in discourses over how to 'fix' Afghanistan.

This article reviews changing images of the international community in the reconstruction of Afghanistan and shows that the challenge faced by NATO and other Western governments and institutions has not just led to efforts at increasing coordination but also to discussions over the potential contribution of regional actors. The article discusses this potential contribution but concludes that the formulation of a regional strategy is hampered by the heterogeneity of political and security concerns in Afghanistan's neighborhood and the lack of an overarching political strategy towards Afghanistan on the part of Western actors. It also concludes that the current discourse of a regional approach coupled with a renewed emphasis on the UN in coordinating international efforts have brought debates over engagement in Afghanistan full circle. In light of a continued Western lead in both military and ideational terms, 
however, the involvement of the 'international community' in developing a common strategy that includes regional actors seems unlikely.

\section{The international community in Afghanistan: changing images (and actors)}

At the outset of the US-led military intervention and international reconstruction efforts in Afghanistan, the image of the international community and particularly a consensus between Western, non-Western and Islamic states, was given prevalence in the formulation of international policy towards Afghanistan. The UN assumed a central role in reconstruction and the creation of an interim government. At the Bonn Conference on the future of Afghanistan in December 2001, Afghan factions agreed on a transitional process leading to elections of a 'broad-based, gender-sensitive, multi-ethnic and fully representative government' (United Nations 2001) and established the Afghan Interim Authority (AIA) under the leadership of Hamid Karzai who, after the presidential elections in December 2004 , became the first democratically elected president of the Islamic Republic of Afghanistan.

Emphasizing broad international participation, the military aspect of reconstruction by means of the International Security Assistance Force (ISAF), the peacekeeping force assembled under the framework of UNSC Resolution 1378 was undertaken without the participation of US forces. Initially at least, NATO did not play a role in ISAF. Its involvement was blocked by several NATO countries, including France, that were not eager to see a 'NATO flag fly in Kabul' (NATO Notes 2002). The importance attached to more than just Western presence in Kabul was also highlighted by the fact that Turkey assumed command over ISAF after the initial six-month British lead. Apart from military contributions to ISAF, individual countries have also contributed to the reconstruction of Afghanistan by assuming coordinating roles in a number of areas within Security Sector Reform (SSR): justice reform (Italy); counter narcotics (UK); police (Germany); military (USA); Disarmament, Demobilization and Reintegration (DDR) (Japan).

Initial emphasis, therefore, was on the 'international community' and its individual rather than institutional members that were committed to the reconstruction of Afghanistan. There also was an emphasis on the involvement of a Muslim country - Turkey - in the military efforts under ISAF; and there was an explicit emphasis on a speedy transition to Afghan ownership of the post-conflict state-building process enshrined in the 'light footprint' concept. In practice, the 'international community' consisted mainly of the US, the UN, key lead nations in individual policy areas, and the EU. Over time, also in light of NATO assuming command of ISAF as of August 2003, transatlantic arguments over burden sharing and a division of labor between NATO and the EU, meant that the focus increasingly shifted from ensuring broad contributions to the reconstruction of Afghanistan to debates over differences between alliance members over size and nature of their individual military contributions. The emphasis on the activities of the international community in the reconstruction of Afghanistan subsequently turned into debates over different levels of financial and military contributions as well as approaches towards reconstruction. The increasing fragmentation of international presence under a de facto Western lead thus came to undermine the image of 'the international community' - and the absence of an overall political strategy towards rebuilding the Afghan state further highlighted the lack of not just a Western but also an international consensus on Afghanistan.

\section{Applying concepts: Western state-building and Afghan realities}

International intervention in Afghanistan is located in a specific ideational context that reinforces the Western material lead of military efforts: that of state failure and resulting humanitarian emergencies - but also the link to international terrorism. Since the end of the Cold War the concept of failed or failing states became key in understanding how weak state structures and illegitimate governments formed preconditions for an increase in organized crime, breakdown of social structures, human rights violations and the emergence of transnational terrorist networks (Schneckener 2007). The attacks of 11 September and the emerging paradigm of the 'war on terror' have since reinforced the conceptual connection between weak or failed states and international terrorism - and have made the challenge of preventing state-failure and that of (re-)-building failed states a central concern for international crisis management policies. Security sector reform (SSR) in particular has become a key concept for improving governance in post-conflict countries (Hänggi and Tanner 2005).

The lack of consensus among the international community but also among the West is also reflected in the insufficient intellectual engagement with the concepts that underpin reconstruction efforts. Western liberal conceptions of the role of the state, and the value of democracy promotion that form the overall ideational basis for state-building and post-conflict reconstruction (Jahn 2007), have turned out to be less than appropriate for the particular context in which they are placed - and have further hampered moves towards the formulation of an international rather than Western-dominated strategy towards Afghanistan. Afghanistan presents a case where traditional decision-making structures and political affiliations tend to be local and not easily subsumed under the centralized, democratic state-model current reconstruction efforts are built on. While formal institutions have been established, these are not self-sustaining, with $93 \%$ of the budget continuing to be financed through external sources, thereby cementing Afghan dependence on international aid (Maas 2007; on the effect on governance Kühn 2008).

With respect to SSR, the legacy of Soviet occupation and Taliban rule along with international isolation has meant that a functioning police and justice sector did not exist in Afghanistan (Wilder 2007; Thier 2004). In addition, active military operations take place alongside state- and institution-building efforts on the part of the international actors. The narcotics trade in particular fuels insurgency, corruption and state weakness. Lastly, Afghanistan's economy is recovering from decades of conflict. Despite some progress - GDP per capita growth ex- 
ceeded 9\% in 2007 - Afghanistan remains extremely poor and most of the population continues to suffer from shortages of clean water, electricity, and medical care (World Bank 2008). The post-conflict setting, coupled with a large rural population - only $24 \%$ of the population lives in cities - makes reaching the part of the population living outside of major cities challenging.

Increasingly, the applicability of Western approaches to state building and post-conflict reconstruction, including the emphasis on SSR, has been put into question (Sedra 2006). Afghanistan thus challenges such concepts, which form key building blocks in the overall state-building efforts, and the attempt at establishing centralized democratic structures in an insecure location. This further undermines not just the success of international efforts but also reinforces the Western conceptual bias that underpins these efforts - and makes arriving at a local and international consensus all the more challenging.

\section{Increasing fragmentation: transatlantic and intra-European differences}

Growing security concerns coupled with debates over alliance solidarity and military commitments soon turned out to be fragmenting not just international, but increasingly also Western efforts. It also became clear that ISAF did not succeed at filling the security vacuum left after the fall of the Taliban, and the neglect of police and justice reform together with an overall lack of military, political and economic resources invested is now universally recognized as a 'missed opportunity' on the part of the international community. The debate over Afghanistan moved from one that emphasized involvement of the 'international community' to one that predominantly concerned the size and nature of European contributions and the involvement of NATO. The war in Afghanistan clearly redefined NATO's role, and most public debate centered on the challenge posed to NATO, as well as the nature of military contributions. Essentially, Afghanistan was a US-led intervention, and US predominance in determining the political parameters of international engagement also extended to reconstruction tasks, as the US continues to far outspend the Europeans in military commitments, police reform and development aid (Korski 2008). Differences across the Atlantic, but also within Europe, continue to centre on the establishment of viable governance structures in an environment with high levels of corruption, a growing narcotics trade and insufficient economic development. Police reform in particular has become one of the key priorities in efforts at establishing the rule of law.

European efforts at SSR, specifically EU contributions to reforming the Afghan National Police (ANP), further illustrate the extent of transatlantic differences in both material and ideational terms. Since June 2007, police reform has been 'Europeanized' through the European Police Mission (EUPOL Afghanistan) that took over from the German Police Project Office (GPPO) the task of advising the ANP on reform efforts and of coordinating the international partner contributions. EUPOL Afghanistan is embedded in the larger EU commitment to Afghanistan. This includes the appointment of an EU Special Representative and financial contributions from the European
Commission, which has given some EUR 135 million to the Law and Order Trust Fund (LOTFA) that pays for police salaries since 2002; and has allocated more than EUR 10 million to the Provincial Reconstruction Teams (PRTs) that support a range of European projects in different parts of the country (Council of the European Union 2007).

But, a significant discrepancy in resources committed between the US and the EU in the field of police reform reinforces the fragmentation among Western actors. Compared to that of the United States, another key actor in police reform with 500 contracted police trainers, 750 military personnel and $\$ 2$ billion in funding in particular, the size of the EU's commitment is comparatively small. What is more, the underlying philosophy on police training differs: US training has focused on equipment and rapid training rather than emphasizing institutional reform in favor of more accountability. Different conceptions of the role and purpose of the security sector, and different underlying conceptions of the task to be accomplished - institution-building on the part of the EU and the contextualization of efforts as part of the broader war on terror on the part of the US - are thus reproduced in specific tasks and aspects of statebuilding on the ground. The contradictions and differences among 'the West' are also visible in so far as emphasis tends to be on NATO's military efforts and on transatlantic burden sharing. This results from the widely different level of funding committed to military deployment as opposed to civilian reconstruction efforts. Beyond emphasizing the military over development and institution-building efforts, highlighting different levels of commitment reinforces the fragmentation among members of the transatlantic alliance. In the discourse on international interventions NATO takes predominance - but increasingly seeks to rely on other actors, notably the EU but also non-governmental organizations (NGOs) in its pursuit of a 'comprehensive approach' that fuses military and civilian instruments (Jakobsen 2008).

\section{Changing narratives in rescue of 'the West': from light footprint to coordination}

Within Western - US, European, EU and NATO - efforts, therefore, different and evolving narratives and scripts of 'the West' and its various contributions to post-conflict reconstruction exist. Notably, these narratives have been predominantly that of NATO. The alliance fundamentally shifted its role in response to the presumed choice between 'out of area or out of business' in light of post-11 September security priorities. Increasing challenges to NATO's success in Afghanistan, due to the growing insurgency in addition to the drug trade and its various effects on government legitimacy and security, meant that the success of NATO and debates over alliance solidarity became prevalent in the discourse on Afghanistan. The emphasis on the 'international community' was thus replaced with that of solidarity within the Western alliance. Operational experience gathered in this particular mission, however, led NATO to attempt to re-brand itself into an institution concerned with more than providing military security, but one that could deliver a 'comprehensive approach' that fuses security and development. This in turn raised the issue over competition with the 
EU, and the compatibility of military and non-governmental or humanitarian actors. More broadly, it also shows that in the conceptualization of its new role and doctrine in Afghanistan, NATO assumed leadership in areas - military, civilian and developmental - that were previously to be shared among the international community.

Partly as a result of NATO assuming the lead in debates over security and development - also in light of its lead in both material as well as conceptual commitments - the role of the UN, although it was entrusted with coordinating efforts, has not been very visible. Therefore, discussion continues to centre around European and transatlantic efforts and how they support the UN rather than on prominence of the UN and the international community. The UN continues to be a legitimizing actor, but it is not an actor that sets or coordinates policy - rather, the debate shifted towards that of a division of labor between Western governments and institutional actors. However, the deteriorating security situation and the resulting risk of failure of international efforts in Afghanistan have effected a rethinking of the nature and strength of international involvement.

Efforts have moved away from the 'light footprint' as a guiding principle, not just with respect to international involvement but also to increasing coordination with the Afghan government. The 2006 Afghanistan Compact, which followed the end of the Bonn process, emphasized partnership between the Afghan government and international institutions; and, through the Afghanistan National Development Strategy (ANDS), seeks to 'work toward a stable and prosperous Afghanistan, with good governance and human rights protection for all under the rule of law', which indicates a move away from the 'light footprint' towards a focus on accountability (Ayub and Kuovo 2008).

The lack of progress in establishing functioning and legitimate government structures has also resulted in increasing attention to the quest for coherence and the formulation of a coordinated political strategy (Centre for the Study of the Presidency 2008), which points towards efforts to unite Western agendas. Giving the UN a stronger coordinating role signals a move towards a more concerted engagement of the UN. This has been reaffirmed by the appointment of Kai Eide as UN Special Representative in Afghanistan in 2008 - although the decision not to appoint a personality with a higher international profile has put into question the extent to which the coordination role will be put into practice.

\section{Regional and geo-strategic perspectives: bringing the region back in}

Aside from confronting difficulties in reconciling different conceptions and approaches towards Afghanistan, Western actors have increasingly looked beyond Afghanistan and their own engagement in the country to explore the impact, but also the potential role, of regional actors in Afghanistan. The parallel discourses over encouraging Afghan ownership in reconstruction and development and of involving regional actors in the quest of an 'Asian solution' to Afghanistan, signals a broadening of thinking in how to approach Afghanistan.
The question of how international intervention in Afghanistan fits the geographically more immediate local and regional context has become more important. Attempts to involve regional actors in Afghanistan serve a dual purpose of being able to scale down Western commitments, but also to legitimize Western efforts towards a regional solution. Particularly noticeable is the increasing attempt to link efforts on Afghanistan with those on Pakistan at the political level, especially on the part of the US.

Moving from the international community to the regional community involves conceptualizing an approach towards $\mathrm{Pa}$ kistan, and to a lesser extent also Iran. It further involves emphasis on greater involvement by India, albeit without offsetting a regional balance as the strengthening of India-Afghanistan ties has been regarded with distrust by Pakistan (Kumar 2008). In the aftermath of the Mumbai bombings and tense relations between the two countries, constructive cooperation with respect to Afghanistan seems unlikely in the near term. With respect to Iran, the unwillingness of the previous US administration to engage in direct talks with Iran harms the formulation of joint policies (or even the exploration of such potential). The extent to which the new US administration will depart from previous approaches of non-engagement remains to be seen, although the signs so far have been encouraging.

Although the centrality of Pakistan to a stable Afghanistan has been recognized, weak state structures signal not just that Pakistan is some way away from playing a constructive role. Combined with US military engagement in Pakistan and the continued emphasis on the 'war on terror' and increasing military commitments without a political strategy, engagement with Pakistan also shows that engaging Afghanistan's immediate neighbors is hampered by state weakness and broader geopolitical but also ideational positions by what continues to be the primary actor: the US.

Despite the increasing conceptualization of Afghanistan as part of a broader regional complex, where regional countries in the immediate neighborhood can make a contribution, there is little to suggest a radical break from practice to date. More than fostering a regional, let alone international, consensus or a broader view of how to approach security, institution-building and development in Afghanistan, these efforts continue to be based on a Western lead in reconstruction efforts - both in material and ideational terms.

This is partly out of necessity, as the regional actors in question - those in Afghanistan's immediate neighborhood including Pakistan, India, Iran and the Central Asian Republics; and those in the wider region, including China and Russia - do not form a coherent regional block that would either facilitate or assume some Western tasks in Afghanistan's reconstruction. But it is also because the overall approach to reconstruction continues to be not just placed in Western hands, but also based on Western concepts. 'International' efforts continue to overwhelmingly mean 'Western' efforts rather than those based on a local, regional and international consensus on approaches to Afghanistan. 


\section{Conclusion: towards community, coordination - and strategy?}

Much of the international and Western confusion and fragmentation reflects the fact that these policies were created in a time of shock and crisis; the enduring fragmentation of efforts reflects ongoing debates on post-9/11 realities, and disagreements among principal actors in Afghanistan's reconstruction. This resulted in a lack of 'community' - but also of 'strategy'. Despite a degree of operational re-orientation as far as emphasizing accountability and coordination is concerned, this has not fundamentally altered the international approach to Afghanistan. Importantly, much of the debate over Western intervention was not about Afghanistan or Afghan realities. Rather, the debate tended to reflect fundamentally Western priorities over the future of its own institutions, and the relation of individual Western institutions and governments towards one another. The quest for the continued relevance of NATO, coupled with the dispute over the division of labor between NATO and the EU, often eclipsed the needs on the ground - in Afghanistan and beyond. In light of an increasing emphasis on Afghanistan and the questions of governance, rule of law and economic development, international and Western efforts have come full circle to once again emphasize Afghan ownership, but with a stronger engagement of international actors and with greater emphasis on accountability. An additional difference is that present circumstances are far more challenging, given the changing international environment and the increasing strategic challenges inherent in a re-emerging Taliban and enduring al Qaeda activities. While 'the West' is finally addressing the need for a comprehensive strategy, the involvement of all relevant actors and the linkages between security, politics and economic development, conditions on the ground are such that an improvement in the short term at least is questionable. In addition, current debates do not constitute a radical break from past assumptions and approaches. Despite ongoing debates over a renewed focus on Afghanistan and over the need for a political strategy, the extent to which Afghanistan will turn into a concern for the international community as a whole remains doubtful.

\section{Bibliography}

Ayub, Fatima/ Kuovo, Sari 2008, Afghanistan: intervention and the war on terror, in: International Affairs 84:4, 641-658.

Centre for the Study of the Presidency 2008, Afghanistan Study Group Report: Revitalizing our Efforts, Rethinking our Strategies, 30 January.

Council of the European Union 2007, Factsheet: EU Police Mission in Afghanistan (EUPOL AFGHANISTAN), May.

Hänggi, Heiner/Tanner, Fred 2005, Promoting security sector governance in the EU's neighbourhood, Chaillot Paper 80, Paris, EU Institute for Security Studies.

House of Commons 2003, Afghanistan: The Transition from $\mathrm{Hu}$ manitarian Relief to Reconstruction and Development, London, 14 January.
Jahn, Beate 2007, The Tragedy of Liberal Diplomacy: Democratization, Intervention, Statebuilding (Part II), in: Journal of Intervention and Statebuilding 1:2, 211-229.

Jakobsen, Peter Viggo 2008, NATO's Comprehensive Approach to Crisis Response Operations: A Work in Slow Progress, DIIS Report 2008:15, Copenhagen, Danish Institute for International Studies, 8 October.

Korski, Daniel 2008, Afghanistan: Europe's Forgotten War, London, European Council on Foreign Relations, January.

Kühn, Florian P. 2008, Aid, Opium and the State of Rents in Afghanistan: Competition, Cooperation, or Cohabitation?, in: Journal of Intervention and Statebuilding 2:3, 309-327.

Kumar, Radha 2008, Afghanistan - a regional perspective, Issues 27, Paris, EU Institute for European Studies, October.

Maas, Citha 2007, Afghanistan: Staatsaufbau ohne Staat, SWP Studie, February.

NATO Notes 2002, Afghanistan: Still Too ,out of area' for NATO?, 19 December.

Schneckener, Ulrich 2007, International Statebuilding: Dilemmas, Strategies and Challenges for German Foreign Policy, SWP Research Paper 2007/RP 09, Berlin, October.

Sedra, Mark 2006, European Approaches to Security Sector Reform: Examining Trends through the Lens of Afghanistan, in: European Security 15:3, 323-338.

Thier, Alexander 2004, Reestablishing the Judicial System in Afghanistan, CDDRL Working Papers 19:1, Stanford University, 1 September.

United Nations 2001, Agreement on Provisional Arrangements in Afghanistan pending the Re-establishment of permanent government institutions (Bonn Agreement), 7 December, http://www.un.org/News/dh/latest/afghan/afghan-agree.htm (14.01.2009).

Wilder, Andrew 2007, Cops or Robbers? The Struggle to Reform the Afghan National Police, Issue Paper, Afghanistan Research and Evaluation Unit (AREU), July.

World Bank 2008, Afghanistan at a Glance, Washington DC, 24 September. 